\section{memórias}

\section{Geraldo Medeiros-Neto}

Professor do Departamento de Clínica Médica, Faculdade de Medicina da Unipersidade de São Paulo.

\title{
Ulhoa Cintra, Um Pioneivo da Moderna Endocrinologia
}

$\mathrm{O}$ FINAL DO ANO DE 1998 trouxe-nos uma triste notícia: o desaparecimento de nosso convívio, aos 91 anos, do Professor Emérito Antonio Barros de Ulhoa Cintra, da Faculdade de Medicina da Universidade de São Paulo. Neste tradicional Centro de Ensino e Pesquisa todos os alunos de graduação e pós-graduação, funcionários, docentes, auxiliares, assistentes e professores conheciam a figura enérgica, a fisionomia séria, inspirando atenção e respeito, do Professor Cintra. No entanto, nós, pertencentes a Primeira Clínica Médica, que tivemos o privilegio de compartilhar com êle o dia-a-dia da enfermaria e do laboratório, constatamos que debaixo daquela aparente severidade no olhar e da postura altaneira, se delineava e se suavizava, a pessoa do Mestre amigo, indulgente e sorridente, parcimonioso nos elogios, mas sempre incentivando que se buscasse, com afinco, resultados confiáveis, insistindo para que fossem repetidos os testes de laboratório, tantas vezes quanto preciso para não se ter dúvidas, sempre mostrando a necessidade de se ter sempre à mão os valores normais, exaustivamente testados, para fins de comparação. Para os amigos chegados e para a família o sério e teutonico Professor se transformava no "Totó" Cintra, adorado pela família próxima, pelas tias, pelas primas e primos, por parentes chegados e os mais distantes, e por seus numerosos pacientes do Hospital das Clínicas e da clínica particular.

O Professor Ulhoa Cintra era de família tradicional de São Paulo onde nasceu a 13 de setembro de 1907 e sobrinho do Professor de Pediatria, Delphino Pinheiro de Ulhoa Cintra. Sua vocação médica sermpre foi inquestionável, comprovada pelo fato de cursar os anos de graduação com brilhantismo e dedicação, formando-se na Faculdade de Medicina da USP em 1930. Após alguns anos em que considerou a Pediatria como opção ou possibilidade de carreira, mudou de rumo ao tomar conhecimento das novas ideias vindas dos Professores Alemães que vieram se radicar nos EEUU, fugindo do terror nazista implantado por Hitler. No auge da II Grande Guerra, embarca para Boston onde no Massachussetts General Hospital, Harvard Medical School, encontra o Prof. Fuller Albright. Este genial americano, justamente conhecido como o pai da Moderna Endocrinologia, havia lançado revolucionários conceitos sobre moléstias conhecidas e vaticinado que, outros tipos de doenças endócrinas e metabólicas, seriam futuramente descritos.

Como Albright o Prof. Cintra ficou fascinado com as doenças ósseas metabólicas e, voltando ao Brasil, com o auxílio financeiro de amigos dedicados, montou o Scrviço de Moléstias da Nutrição e o Laboratório Metabólico da Primeira Clínica Médica, no Hospital das Clinicas da FMUSP. Era o início da formação de uma pleiade de cientistas, endocrinologistas, especialistas em doenças nutricionais e metabólicas, núcleos de estudo de complicadas afeç̧ões genéticas bem como de novas ideias sobre os distúrbios metabólicos dos pacientes após serem submetidos a cirurgia. O Prof. Cintra foi o indiscutível pioneiro do conceito inovador de que o endocrinologista deve, a par do conhecimento clínico e teórico da doença, 
ter grande familiaridade com o laboratório clínico ou de pesquisa, que the fornece a independência de poder associar as duas vertentes - a clínica de um lado e os resultados do laboratório de outro - discutindo, com igual facilidade, conhecimento e familiaridade a clinica e o laboratório. Em outras palavras "colocou a pipeta na mão do clínico".

Chamado a reger e dirigir a Universidade de São Paulo, como Reitor, e, mais tarde, como Secretário da Educação do Governo Abreu Sodré, realizou um trabalho excepcional conforme bem o atestou o Professor Pires Azanha em seu artigo neste Jornal (31.dez.98).

Passado o período da Reitoria e da Secretaria de Educação, onde conheceu, infelizmente, as ameaças da ditadura militar, por um processo injusto e malévolo, voltou o Prof. Cintra a sua querência, na Faculdade de Medicina, onde continuou a colocar o seu tempo e a sua vida na tarefa de formar Médicos, a descobrir fatos, a elucidar mecanismos de doenças, a curar pacientes, a ensinar muito, a pesquisar continuamente e a deixar em todos um exemplo de Professor Universitário digno deste nome. Mesmo após a sua aposentadoria em 1978 jamais deixou de ir ao Hospital das Clínicas onde assistia e participava de todas as reuniões, compartilhava das visitas à enfermaria, discutia aspectos complexos de casos clínicos complicados, emitia judiciosas opiniões, mostrando uma incrível atualização médica. Os residentes de plantão, aos sábados e domingos, se acostumaram a ver o Professor Cintra, todos os fins de semana, a andar pela Enfermaria da Endocrinologia, a ver os pacientes, a a conversar com os familiares, a animar, a consolar, a explicar e a examinar exercendo a sua função e a sua vocação de médico amigo e dedicado. Até os seus 90 anos sempre passava em minha sala, pela manhã, a dar "dois dedos de prosa" o que em suas palavras, queria dizer: compartilhe comigo o que você está fazendo, o que está surgindo de novo, o que está se pesquisando, quais as novidades médicas e terapêuticas, e como não poderia deixar de ser, um pouco dos rumores e fatos da política universitaria, e da política em geral com leves toques de economia globalizada e dos rumos que estaria tomando o nosso Brasil.

Adeus Mestre: vamos sentir saudade e muita saudade dos seus "dois dedos de prosa" mas temos constantemente na nossa frente a sua extraordinária presença, o seu constante exemplo, as suas admiráveis lições médicas e universitárias, a sua MISSÃO CUMPRIDA, como modelo a ser seguido por todos nós da FMUSP e de outras universidades, como paradigma de educador, médico, professor e homem de ciência.

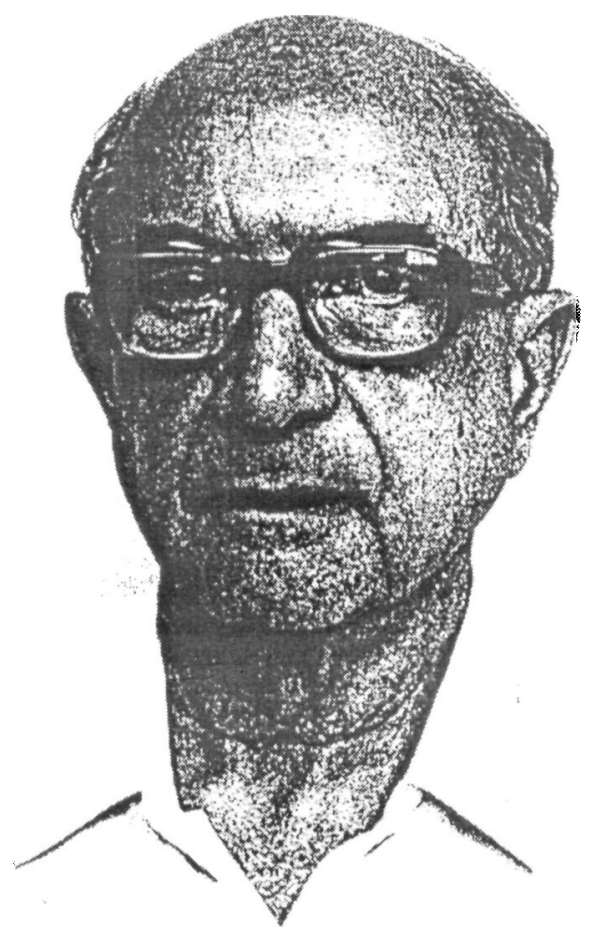

Prof. Antonio Barros de Ulhôa Cintra (1907-1998) 